\title{
Growth and photosynthesis of the 'brown tide' microalga Aureococcus anophagefferens in subsaturating constant and fluctuating irradiance
}

\author{
Allen J. Milligan ${ }^{1, *}$, Elizabeth M. Cosper ${ }^{2}$ \\ ${ }^{1}$ University of British Columbia, Department of Botany, 6270 University Boulevard, Vancouver, British Columbia, Canada V6T 124 \\ ${ }^{2}$ Marine Sciences Research Center, State University of New York, Stony Brook, New York 11794-5000, USA
}

\begin{abstract}
During the summer of 1985, a small (2 to $3 \mu \mathrm{m}$ ) chrysophyte, Aureococcus anophagefferens, bloomed and dominated the phytoplankton assemblage, and recurred each summer for the following 12 yr in bays of Long Island, New York, USA. Macronutrients remained at high levels throughout the years but Secchi disc depths were as low as $30 \mathrm{~cm}$ in some areas, corresponding to a $1 \%$ light depth of about $80 \mathrm{~cm}$. In batch culture, $A$. anophagefferens maintained high growth rates at low irradiances. The initial slope of the growth versus irradiance curve, $\alpha_{1 j}$, was $0.021 \pm 0.003$ divisions $\mathrm{d}^{-1}$ ( $\mu$ mol quanta $\left.\mathrm{m}^{-2} \mathrm{~s}^{-1}\right)^{-1}$ which is similar to that for bloom formers such as Skeletonema costatum. In continuous culture, constant and fluctuating irradiance regimes resulted in equivalent steady state growth rates at 0.46 divisions $\mathrm{d}^{-1}$. Short-term carbon fixation per unit chlorophyll a was about twice as high in the fluctuating irradiance regime compared with constant irradiance. Differences between short-term carbon fixation and cell growth could not be accounted for by dark fixation or exudation and are assumed to be due to photorespiration. The photosynthesis versus irradiance parameter, $P_{\max }$ (light saturated photosynthetic rate), was similar in both irradiance regimes; however, $\alpha_{p}$ (initial slope) was consistently higher in the fluctuating regime, indicating that photosynthetic efficiency is higher in fluctuating ir radiance
\end{abstract}

KEY WORDS: Aureococcus anophagefferens Photoacclimation - Brown tide Fluctuating irradiance

\section{INTRODUCTION}

Great South Bay and the Peconic Bay system of Long Island, New York (USA) are both shallow (1 to $3 \mathrm{~m}$ average depth) well-mixed estuaries. The summer phytoplankton assemblage is typically dominated by nanoplankton (2 to $20 \mu \mathrm{m}$ ) which can contribute greater than $80 \%$ of the total biomass in terms of chlorophyll a (chl a) (Bruno et al. 1983, Lively et al. 1983) and up to $95 \%$ of the total production (Lonsdale et al. 1996). This phytoplankton assemblage supports scallop Argopecten irradians and hard clam Mercenaria mercenaria populations. Primary production for the Great South Bay is high, and has been estimated to be around $450 \mathrm{~g} \mathrm{C} \mathrm{m}^{-2} \mathrm{yr}^{-1}$ (Lively et al. 1983). Shallow

•E-mail:allenm@unxg.ubc.ca benthic communities are dominated by eelgrass Zostera marina which provides a nursery ground for many larval and juvenile finfish species and a substratum for the attachment of juvenile scallops (Dennison et al. 1989)

During the summer of 1985, a small ( 2 to $3 \mu \mathrm{m}$ ), previously undescribed, chrysophyte bloomed and dominated the phytoplankton assemblage of the Long Island bays. Its co-occurrence in both Narraganset Bay, Rhode Island, and Barnegat Bay, New Jersey, suggests involvement of regional meteorological conditions (Cosper et al. 1987, 1989). While the bloom never fully returned to Rhode Island or New Jersey, it recurred sporadically in Long Island bays each summer for the following $12 \mathrm{yr}$

The alga was identified and described by Seiburth et al. (1988) as the chrysophyte Aureococcus anophagef- 
ferens gen. et sp. nov. Examination of its absorption and excitation-emission properties as well as the presence of $19^{\prime}$ butanoyloxyfucoxanthin pigment have indicated that it is particularly suited to a blue light environment and this has led some researchers to hypothesize that $A$. anophagefferens may be an expatriate oceanic species (Bidigare 1989, Yentsch et al. 1989). In laboratory growth experiments A. anophagefferens has a high salinity preference and a wide temperature tolerance which allows it to overwinter in a vegetative state at low growth rates (Cosper et al. 1989). Laboratory and field experiments demonstrated that $A$. anophagefferens has a requirement for selenium and high concentrations ( $\mu \mathrm{M}$ ) of iron (Gobler 1995).

The bloom was first recognized by a golden-brown coloration of the water and high turbidity. Secchi disc depths were as low as $30 \mathrm{~cm}$ in some areas corresponding to a $1 \%$ light depth of about $80 \mathrm{~cm}$. Cell concentrations were as high as $2 \times 10^{6}$ cells $\mathrm{ml}^{-1}$, and estimates of carbon turnover times for the $<5 \mu \mathrm{m}$ size fraction were on the order of $3 \mathrm{~h}$ (Cosper et al. 1987. 1989). Chl a concentration and water column primary production rates were similar to those for non-bloom years, however. The high turbidity has been attributed to increased cell concentrations as well as increased scattering due to the small size of the cell (Cosper et al. 1987, 1989). The severe light attenuation contributed to the mass die-off of eelgrass Zostera marina and a reduction in its maximum depth range, from 3-4 $\mathrm{m}$ pre-1985 to $1.6-2.2 \mathrm{~m}$ in 1988 (Dennison et al. 1989). For reasons probably relating to chronic toxicity, scallops in affected areas experienced complete recruitment failure which resulted in a total loss of the populations (Bricelj \& Kuenstner 1989).

Light availability is a potentially important factor in the blooms of Aureococcus anophagefferens. Macronutrient surveys during bloom periods have shown that nitrogen species $\left(\mathrm{NH}_{4}^{+}, \mathrm{NO}_{2}{ }^{-}, \mathrm{NO}_{3}{ }^{-}\right)$and inorganic phosphorus were in excess at all times, and that nutrient concentrations were not correlated either with variations in biomass or productivity of A. anophagefferens (Cosper et al. 1987, 1989). Lively et al. (1983), in a study of Great South Bay, concluded that mean photic zone irradiance is limiting to primary production at intensities below 300 langley $\mathrm{d}^{-1}(57 \mathrm{~mol}$ quanta $\left.\mathrm{m}^{-2} \mathrm{~d}^{-1}\right)$. Similar results were obtained by Bruno et al. (1983) working in Great Peconic Bay and Flander's Bay (New York) with 280 langley $\mathrm{d}^{-1}$ (53 mol quanta $\mathrm{m}^{-2}$ $\mathrm{d}^{-1}$ ) being limiting.

Efficient light utilization during nutrient saturated conditions could be an important factor in determining plankton species composition. We therefore hypothesize that the ability of Aureococcus anophageffer- ens to maintain high growth rates under low irradiance could be an important contributing factor to its dominance. In addition, the shallow $(80 \mathrm{~cm})$ photic zone observed during periods of maximum biomass combined with wind mixing allows for large fluctuations in the light field experienced by phytoplankton. Fluctuating light influences carbon assimilation and could potentially affect growth rates (Marra 1978). Therefore, carbon assimilation and growth rates of $\mathrm{A}$. anophagefferens are compared in both fluctuating and constant irradiance.

\section{METHODS AND MATERIALS}

Culture methods. Cultures of Aureococcus anophagefferens isolated from Peconic Bay by E.M.C. were grown either in batch or continuous culture with modified f/2 enriched seawater (Guillard \& Ryther 1962). Surface seawater (1000 I; salinity 28) was collected from Peconic Bay at New Suffolk, New York, and stored at $5^{\circ} \mathrm{C}$ in a polyethylene container. Batches (10 l) of seawater were prefiltered through a Gelman $0.2 \mu \mathrm{m}$ cartridge filter and autoclaved for $50 \mathrm{~min}$ at $110^{\circ} \mathrm{C}$ with Tris (hydroxymethyl) aminomethane (THAM) buffer, with vitamins and $\mathrm{NaNO}_{3}$ added. All other nutrients were autoclaved separately and added aseptically after the seawater was cooled in a $10^{\circ} \mathrm{C}$ water bath. Glycerophosphate was used at $f / 2$ concentrations in place of orthophosphate and iron was reduced to $\mathrm{f} / 20$ concentration. Nitrilotriacetic acid (NTA, $5.0 \mu \mathrm{M})$ was used as the chelator in place of Disodium (Ethylenedinitrilo) tetraacetate (EDTA) (Cosper et al. 1993)

The sub-saturating irradiance used for continuous cultures was determined by a growth versus irradiance curve generated using batch cultures. Cultures were grown aseptically in triplicate $6 \mathrm{ml}$ test tubes and were maintained at $23^{\circ} \mathrm{C}$ on a $12 \mathrm{~h}$ light: $12 \mathrm{~h}$ dark cycle in the photosynthetron described below. Growth during acclimation to each irradiance was monitored daily using in vivo fluorescence (Brand et al. 1981) over a period of 2 wk or longer. After the acclimation period, cultures were transferred into fresh medium and growth was followed through the exponential growth phase. All cultures were preserved with Lugol's iodine for microscopic enumeration. Growth rates were calculated using cell number.

Continuous cultures of 51 each were grown in lightlimited cyclostat mode (Rhee et al. 1981) at $18 \pm 2^{\circ} \mathrm{C}$ in a walk-in incubator. A constant average biomass was maintained using a peristaltic pump adjusted to the growth rate of the culture. Light was provided by a GE PAR 500 full spectrum tungsten bulb and filtered through $0.2 \% \mathrm{CuSO}_{4}$ solution with a $27 \mathrm{~cm}$ path length 
to remove infra-red energy and to better simulate the natural light spectrum. Subsaturating irradiance with a $12 \mathrm{~h}$ light:12 h dark photoperiod was provided in 2 ways: as constant irradiance at $70 \mu \mathrm{mol}$ quanta $\mathrm{m}^{-2} \mathrm{~s}^{-1}$ and as fluctuating irradiance, where irradiance was varied as a sine function with an amplitude between 10 and $180 \mu \mathrm{mol}$ quanta $\mathrm{m}^{-2} \mathrm{~s}^{-1}$ and a period of $1 \mathrm{~h}$. Fluctuating irradiance was attenuated with a disk of neutral density nickel screens rotated at 1 cycle per hour, consistent with possible Langmuir circulation rates (Cosper 1982b). Both irradiance treatments provided an equal daily quantum flux of 3.1 mol quanta $\mathrm{m}^{-2} \mathrm{~d}^{-1}$ Irradiance was measured using a quantum meter (Biospherical Instruments QSL-100) fitted with a $4 \pi$ sensor.

Once the cultures reached steady state, cells were sampled for photosynthetic rate, organic carbon excretion rate, and chl a specific absorption cross-section $\left(\bar{a}^{*}\right)$ on 3 consecutive days at 2 and $6 \mathrm{~h}$ after the onset of the light period. These time points were chosen to include maximum photosynthetic rates ( 6 h) and submaximum rates ( $2 \mathrm{~h}$ ). Photosynthesis versus irradiance $(P$ vs $I)$ curves were also generated for both time points. Samples were also collected and stored frozen for determination of chl a, carbon and nitrogen per cell, and fixed with Lugol's iodine for cell number.

Cell division. Specific growth rates in the continuous culture were calculated at steady state using the equation

$$
\mu=v \cdot V_{r}^{-1}
$$

where $v$ is the volume in liters of medium added per day and $V_{\mathrm{r}}$ is the volume of the culture $\left(V_{\mathrm{r}}=5 \mathrm{l}\right)$. Cell counts were performed microscopically at the same time each day, using a hemacytometer to determine when steady state was reached, and at each time point during the experimental period. At least 8 counts were performed for each time point.

Photosynthesis and excretion. Photosynthesis versus irradiance curves were obtained using the photosynthetron protocol of Lewis \& Smith (1983). Incubations were run for $20 \mathrm{~min}$. Rates at $70 \mu \mathrm{mol}$ quanta $\mathrm{m}^{-2} \mathrm{~s}^{-1}$ are reported as short-term carbon fixation. Ten irradiances were used and the data fit to Eq. (2) (from Platt \& Gallegos 1980) using non-linear regression.

$$
P_{\mathrm{B}}=P_{\mathrm{s}}\left(1-\mathrm{e}^{-\mathrm{a}}\right) \mathrm{e}^{-\mathrm{b}}
$$

where $P_{\mathrm{B}}$ is the photosynthetic rate normalized to chl $a_{\text {; }}$ $\mathrm{a}=\alpha E / P_{\mathrm{s}}$ and $\mathrm{b}=\beta E / P_{\mathrm{s}} ; P_{\mathrm{s}}$ is the maximum photosynthetic rate that would be achieved if no photoinhibition occurred; and $\alpha$ is the initial slope of the curve, $\beta$ is the slope of the descending branch of the curve, and $E$ is the scalar irradiance. Eq. (2) was also used in modified form to calculate the initial slope of the growth versus irradiance curve and the light saturated growth rate, where $\alpha_{\mathrm{g}}$ (the initial slope of the growth vs irradiance curve) is substituted for $\alpha, G_{\max }$ (maximum growth rate) is substituted for $P_{\mathrm{s}}$ and the growth rate (divisions $\mathrm{d}^{-1}$ ) is substituted for $P_{\mathrm{B}}$.

Reported values for long-term light and dark carbon fixation rates were estimated using $2 \mathrm{~h}$ incubations with ${ }^{14} \mathrm{C}$ bicarbonate. Approximately $15 \mu \mathrm{Ci} \mathrm{NaH}{ }^{14} \mathrm{CO}_{3}$ was added to two $60 \mathrm{ml}$ aliquots of culture and incubated for $2 \mathrm{~h}$ in a light bottle and a dark bottle adjacent to the continuous culture. Excretion of organic carbon in each bottle was estimated following Cosper (1982a). The filtrate from $0.45 \mu \mathrm{m}$ nitrocellulose filters (Millipore) was acidified with $\mathrm{HCl}$ to a $\mathrm{pH}$ of 2 and aerated for $2 \mathrm{~h}$. Activity of all ${ }^{14} \mathrm{C}$ samples was measured using scintillation counting.

Chlorophyll a. Triplicate $10 \mathrm{ml}$ aliquots were filtered onto $13 \mathrm{~mm}$ Gelman AE glass fiber filters and stored frozen at $-20^{\circ} \mathrm{C}$ in $15 \mathrm{ml}$ polycarbonate centrifuge tubes. Pigments were extracted in $10 \mathrm{ml} 90 \%$ acetone for $24 \mathrm{~h}$ at $5^{\circ} \mathrm{C}$. Samples were centrifuged for $5 \mathrm{~min}$ at $920 \times g$ in a bench top centrifuge to remove any filter debris and were measured fluorometrically on a Turner Designs fluorometer (Strickland \& Parsons 1972). Chl a was calculated using fluorescence values before and after acidification with a few drops of $10 \% \mathrm{HCl}$. The fluorometer was calibrated against a Spectronic 1201 spectrophotometer using $90 \%$ acetone extracted chl a from an actively growing culture of Thalassiosira weissflogii (Jeffrey \& Humphrey 1975).

CHN analysis. Triplicate $10 \mathrm{ml}$ aliquots of culture were filtered onto precombusted $13 \mathrm{~mm}$ Gelman AE glass fiber filters and analyzed by the Nutrient Analytical Laboratory of the Chesapeake Bay Laboratory using standard gas chromatographic methods.

Absorption cross-section $\left(\overline{\mathbf{a}}^{*}\right)$. In vivo attenuation (absorption not corrected for scattering) was obtained on whole cell suspensions in a $10 \mathrm{~cm}$ cuvette using a Spectronic 1201 spectrophotometer. The spectrally averaged, chl a specific absorption cross-section was calculated according to Falkowski et al. (1985):

$$
\bar{a}^{*}=\sum\left(a_{\dot{\lambda}} \cdot \mathrm{I}_{\lambda} \cdot \Delta \lambda_{n}\right) \cdot\left[\sum\left(\mathrm{I}_{\lambda} \cdot \Delta \lambda\right)\right]^{-1}
$$

where $\bar{a}^{*}$ is the spectrally averaged, chl a absorption cross-section $\left(\mathrm{m}^{2} \mathrm{mg}^{-1} \mathrm{chl} a\right), a_{i}^{*}$ is the wavelength specific absorption cross-section, $\Delta \lambda$ is the wavelength interval of the spectral bandn and $I_{\lambda}$ is the irradiance in the spectral band $\Delta \lambda_{n}$.

Statistical analyses. Results were analyzed using 1-way and 2-way analysis of variance (ANOVA) after determining homogeneous variance using the methods of Sokal \& Rohlf (1981). Samples taken from continuous cultures on consecutive days were considered independent. 


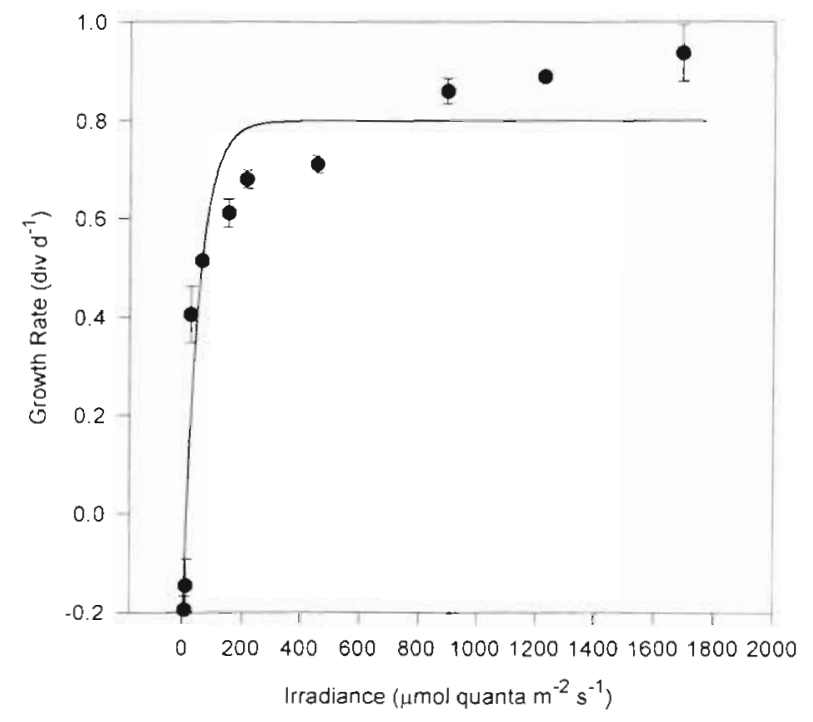

Fig. 1. Aureococcus anophagefierens. Growth rate at various irradiances for batch cultures shown with model fit to data (Eq. 2). $\alpha_{g}=0.021$ divisions $\mathrm{d}^{-1}$ ( $\mu \mathrm{mol}$ quanta $\left.\mathrm{m}^{-2} \mathrm{~s}^{-1}\right)^{-1} \cdot G_{\operatorname{miax}}=$ 0.8 divisions $\mathrm{d}^{-1}$ Error bars show $\pm 1 \mathrm{SD}(\mathrm{n}=3)$

\section{RESULTS}

\section{Growth versus irradiance}

The growth rate versus irradiance curve generated for batch cultures of Aureococcus anophagefferens shows that the growth efficiency $\left(\alpha_{g}\right)$ was $0.021 \pm$ 0.003 divisions $\mathrm{d}^{-1}$ ( $\mu$ mol quanta $\left.\mathrm{m}^{-2} \mathrm{~s}^{-1}\right)^{-1}$ when fitting the data to Eq. (2) $\left(r^{2}=0.89\right)$. The half saturating growth irradiance $I_{\mathrm{k}}$ was $69 \mu \mathrm{mol}$ quanta $\mathrm{m}^{-2} \mathrm{~s}^{-1}$ (Fig. 1). Negative growth rates at the lowest irradiances ( 8 and $11.5 \mu \mathrm{mol}$ quanta $\mathrm{m}^{-2} \mathrm{~s}^{-1}$ ) were probably not representative of the compensation irradiance considering that in vivo fluorescence showed that these cells were actively producing pigment.

\section{Light treatments}

Steady state growth rates of continuous cultures grown under constant and fluctuating irradiance were equivalent at 0.456 divisions $\mathrm{d}^{-1} \pm 0$ and 0.461 divisions $\mathrm{d}^{-1} \pm 0.047$ respectively. Long-term carbon fixation rates ( $2 \mathrm{~h}$ incubation) were also similar, but short-term carbon fixation rates ( $20 \mathrm{~min}$ incubation) in fluctuating irradiance were about twice as high as in constant irradiance $(p<0.01$, Fig. 2A). Higher short-term carbon fixation rates cannot be accounted for either in longterm excretion of organic carbon, which was significantly higher $(p<0.05)$ in constant irradiance, or in long-term dark carbon fixation, which was not significantly different in either treatment.

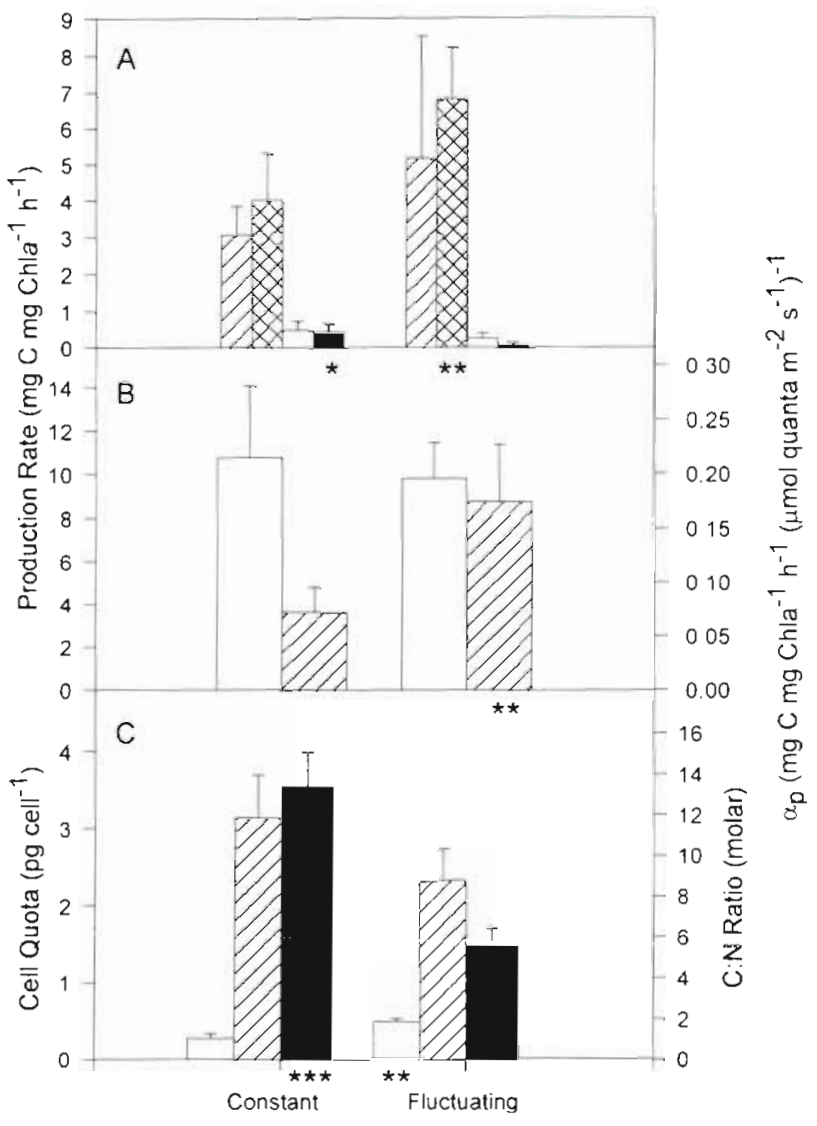

Fig. 2. Aureococcus anophagefferens. Comparison of photosynthetic rates and cell quotas for constant and fluctuating irradiance regimes. Morning and noon values pooled for illustration only. Significance values based on 2-way ANOVA of unpooled data: $\star 0.05, \star \star 0.01, \star \star 0.001$. (A) Long-term carbon fixation rate $(2 \mathrm{~h}, \nabla)$, short-term carbon fixation rate $(20 \mathrm{~min}$, $\bigotimes)$, dark carbon fixation rate $(2 \mathrm{~h}, \square)$, carbon excretion rate $(2 \mathrm{~h}, \boldsymbol{\square})$. (B) $P$ vs I parameters. Maximum photosynthetic rate, $P_{\max }$ (left axis, $\square$ ), initial slope $\alpha_{\mathrm{p}}$ (right axis, $\square$ ). (C) Nitrogen cell ${ }^{-1}$ (left axis, $\square$ ), carbon cell ${ }^{-1}$ (left axis, $\square$ ), C:N ratıo (right axis, $\square$ ). Error bars are $+1 \mathrm{SD}$

The initial slope of the $P$ versus $I$ curve $\left(\alpha_{p}\right)$ was significantly higher $(\mathrm{p}<0.01)$ under fluctuating irradiance indicating a higher photosynthetic efficiency, while the light saturated photosynthetic rate $\left(P_{\max }\right)$ was not significantly different in either treatment (Fig. 2B). Photoinhibition was induced during incubation for cells grown in the fluctuating irradiance treatment $(\beta=$ $3.10 \times 10^{-3} \pm 9.32 \times 10^{-4}$ ) but not in cells grown in constant irradiance $\left(\beta=6.37 \times 10^{-4} \pm 6.49 \times 10^{-4} ;\right.$ Fig. 3$)$.

Carbon per cell in constant irradiance was higher but was not significantly different from the fluctuating irradiance treatment (Fig. 2C). Nitrogen per cell was significantly higher $(p<0.01)$ in fluctuating irradiance and this leads to a significantly lower $(p<0.001) \mathrm{C}: \mathrm{N}$ ratio in fluctuating irradiance (Fig $2 \mathrm{C}$ ). The spectrally 


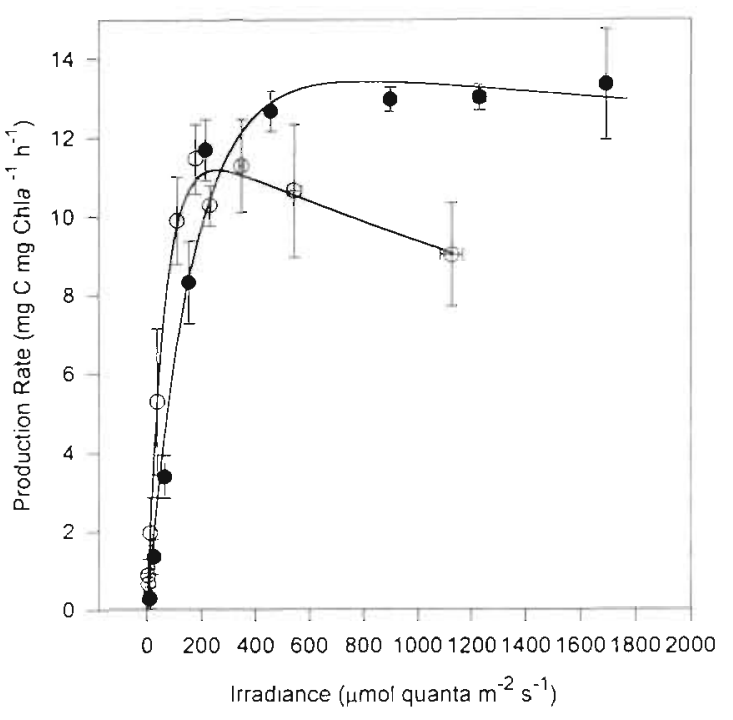

Fig. 3. Aureococcus anophagefferens. Noon time photosynthetic rates at various irradiances for constant ( ) and fluctuating (O) irradiance regimes and model fit to data (Eq. 2). Error bars show $\pm 1 \mathrm{SD}(\mathrm{n}=6)$

averaged chlorophyll a absorption cross-section $(\bar{a} \cdot)$ was lower in fluctuating irradiance (Table 1); however, chl a per cell was similar (insignificant differences) in both treatments. Differences in absorption cross section were also reflected in the in vivo attenuation spectra which was significantly higher $(p<0.001)$ in the Soret region of the spectra in fluctuating irradiance (Fig. 4). The differences in attenuation spectra were determined from a 2-way ANOVA performed on the absorbance at $450 \mathrm{~nm}$, which is near the peak absorbance for chl c, fucoxanthin and 19 'butanoyloxyfucoxanthin (Bidigare 1989).

Table 1. Parameters used in calculation of quantum efficiency of growth $\left(\phi_{\mu}\right)$. See text for definitions of variables

\begin{tabular}{|c|c|}
\hline Variable & Value (units) \\
\hline \multicolumn{2}{|c|}{ Constant irradiance (12 h light: $12 \mathrm{~h}$ dark) } \\
\hline$\mu$ & $0.32\left(\mathrm{~d}^{-1}\right)$ \\
\hline $\bar{a} \cdot$ & $0.0069\left(\mathrm{~m}^{2} \mathrm{mg} \mathrm{chl} \mathrm{a}^{-1}\right)$ \\
\hline Chl a & $\left.0.037(\mathrm{pg} \mathrm{cell})^{-1}\right)$ \\
\hline Carbon & $\left.3.145(\mathrm{pg} \mathrm{cell})^{-1}\right)$ \\
\hline Calculated $\phi_{\mu}$ & 0.104 (carbon-atoms photon ${ }^{-1}$ ) \\
\hline Calculated $1 / \varphi_{\mu}$ & 9.46 (photons carbon-atom ${ }^{-1}$ ) \\
\hline \multicolumn{2}{|c|}{ Fluctuating irradiance ( $12 \mathrm{~h}$ flucuating light: $12 \mathrm{~h}$ dark) } \\
\hline$\mu$ & $0.32\left(\mathrm{~d}^{-1}\right)$ \\
\hline $\bar{a}^{\cdot}$ & $0.0054\left(\mathrm{~m}^{2} \mathrm{mg} \mathrm{chl} a^{-1}\right)$ \\
\hline Chl a & $0.029\left(\mathrm{pg}\right.$ cell $\left.{ }^{-1}\right)$ \\
\hline Carbon & $2.33\left(\mathrm{pg} \mathrm{cell}{ }^{-1}\right)$ \\
\hline Calculated $\phi_{\mu}$ & 0.125 (carbon-atoms photon ${ }^{-1}$ ) \\
\hline Calculated $1 / \phi_{H}$ & 7.95 (photons carbon-atom ${ }^{-1}$ ) \\
\hline
\end{tabular}

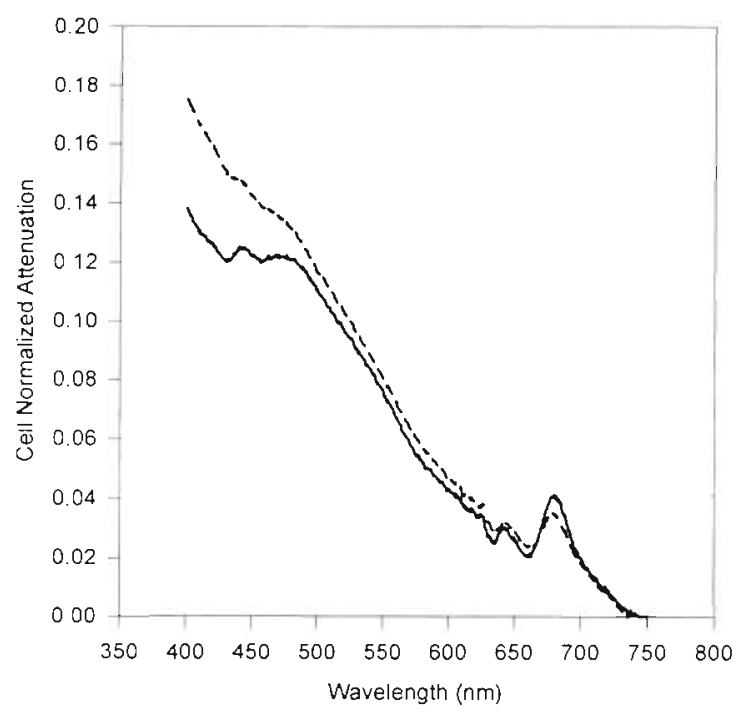

Fig. 4. Aureococcus anophagefferens. In vivo attenuation spectra normalized to cell number grown under constant (solid line) and fluctuating (broken line) irradiance

\section{DISCUSSION}

\section{Light}

While several authors have concluded that primary production in the bays of Long Island is often light limited, the question remains whether all macro and micronutrients were saturating during the blooms of Aureococcus anophagefferens (Bruno et al. 1983, Lively et al. 1983). In an effort to objectively assign light limiting or nutrient saturating conditions, Bannister (1974a) introduced 2 equations which predict maximum areal biomass in terms of chl a and maximum areal production under nutrient saturating conditions and, in a companion paper (Bannister 1974b), used them to define nutrient saturation in several lakes. Both equations require the assumption of steady state phytoplankton production and grazing pressure as well as the assumption of a homogeneously mixed water column which absorbs most of the incident light. The latter assumption is satisfied in bays of Long Island. It is unknown whether the former assumption is satisfied. The driving variables in both equations are the incident irradiance, $I_{0}$, the extinction coefficient of water, $k_{\mathrm{w},}$ the concentration of chl $a_{1}$ the extinction coefficient of the phytoplankton, $k_{\mathrm{c}}$ and the efficiency of the conversion of absorbed quanta to photosynthetic products, $\phi_{\max }$.

The maximum biomass of a totally absorbing, wellmixed water column can be calculated from the equation (Bannister 1974b): 


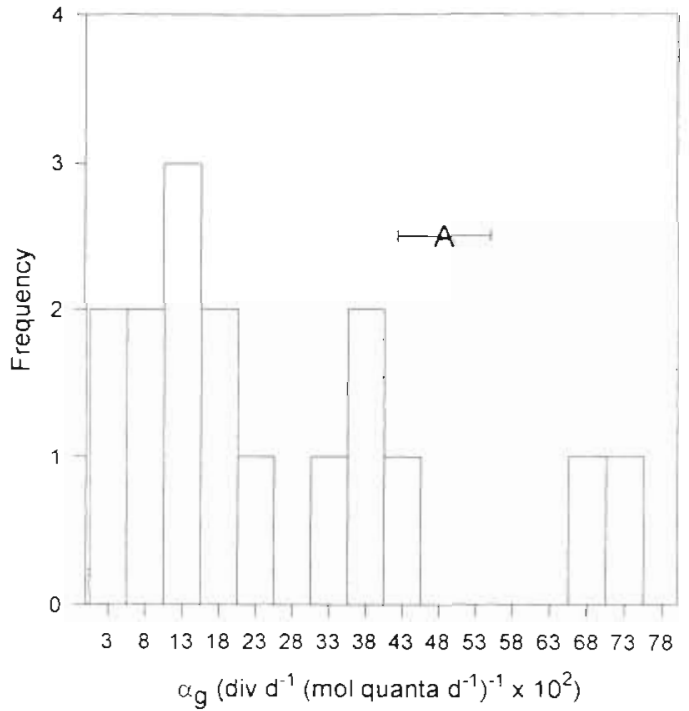

Fig. 6. Frequency distribution of 16 growth efficiencies $\left(\alpha_{g}\right)$ as reviewed by Langdon (1988) with the value for Aureococcus anophagefferens (A) plotted with $95 \%$ confidence limits. All growth efficiencies were normalized to daylength

appears unlikely that irradiances as high as $55 \mathrm{~mol}$ quanta $\mathrm{m}^{-2} \mathrm{~d}^{-1}$ would result in light limitation as this corresponds to a mean instantaneous irradiance of $1100 \mu \mathrm{mol}$ quanta $\mathrm{m}^{-2} \mathrm{~s}^{-1}$

The growth versus irradiance curve for Aureococcus anophagefferens shows that this species has a high growth efficiency. The $\alpha_{\mathrm{g}}$ (the initial slope) value was $0.021 \pm 0.003$ divisions $\mathrm{d}^{-1}$ ( $\mu \mathrm{mol}$ quanta $\left.\mathrm{m}^{-2} \mathrm{~s}^{-1}\right)^{-1}$ or $0.49 \pm 0.065$ divisions $\mathrm{d}^{-1}$ (mol quanta $\left.\mathrm{m}^{-2} \mathrm{~d}^{-1}\right)^{-1}$ when normalized to daylength and falls into the high end of measured growth efficiencies (Fig. 6). For comparison, each growth efficiency, as reviewed by Langdon (1988), has been normalized to daylength by using light periods from original manuscripts. Typical values range from 0.097 to 0.73 divisions $\mathrm{d}^{-1}$ (mol quanta $\mathrm{m}^{-2}$ $\mathrm{d}^{-1} \mathrm{~J}^{-1}$ In general A. anophagefferens is similar in its growth efficiency to diatoms such as the 'bloom' former Skeletonema costatum $\left[\alpha_{g}=0.49\right.$ divisions $\mathrm{d}^{-1}$ (mol quanta $\left.\mathrm{m}^{-2} \mathrm{~d}^{-1}\right)^{-1}$, Langdon 1987] and Leptocylindrus danicus $\left[\alpha_{\mathrm{g}}=0.39 \text { divisions } \mathrm{d}^{-1} \text { (mol quanta } \mathrm{m}^{-2} \mathrm{~d}^{-1}\right)^{-1}$, Verity 1981]. A anophagefferens would therefore be expected to maintain a growth rate under severe light limitation which would be competitive with other known bloom formers. However, during the period in which blooms of $A$. anophagefferens form, usually mid-summer, large diatoms such as $S$ costatum and $L$. danicus are not present in Long Island bays

Light utilization efficiency can also be assessed by calculating the quantum efficiency of growth $\phi_{\mu}$, which is the efficiency of the conversion of absorbed quanta to carbon which is retained for growth (excludes carbon lost to respiration, photorespiration and excretion) and is given in units of moles of carbon (mol quanta) $)^{-1} . \phi_{\mu}$ can be calculated from the equation (Falkowski et al. 1985):

$$
\phi_{\mu}=\mu \cdot\left[\bar{a} \cdot(\operatorname{chl} \mathrm{C}) \cdot I_{0} \cdot 12000\right]^{-1}
$$

where $\mu$ is the specific growth rate of carbon $\mathrm{d}^{-1}$, chl:C is the weight ratio (in $\mathrm{g}$ ) of chl a to carbon per cell, $I_{0}$ is the incident irradiance in mol quanta $\mathrm{m}^{-2} \mathrm{~d}^{-1}$, and $\bar{a}^{*}$ is the spectrally averaged, chl a specific absorption crosssection calculated according to Eq. (3). The constant 12000 converts mg carbon to moles carbon. All parameters used are given in Table 1.

The calculated quantum requirements $\left(1 / \phi_{\mu}\right)$ for Aureococcus anophagefferens grown under constant and fluctuating irradiance are 9.5 photons carbonatom ${ }^{-1}$ and 7.9 photons carbon-atom ${ }^{-1}$ respectively. These values appear unlikely as they are close to the theoretical limit for photosynthesis ( 8 photons carbonatom ${ }^{-1}$ ) and well below reported values which range from 20 to 180 (Falkowski et al. 1985). It is possible that A. anophagefferens could be supplementing its carbon demand by using dissolved organic carbon (DOC). This would violate the implicit assumption of photolithotrophy in the above model and explain low quantum requirements. Dzurica (1988) has shown that $A$. anophagefferens can rapidly assimilate glutamic acid, and this source could supply up to $200 \%$ of the carbon and nitrogen demands of $A$. anophagefferens over short-term incubations ( $3 \mathrm{~h}$ ). Using the photosynthetic rates for constant irradiance from morning $(3 \mathrm{~h})$ and noon ( $6 \mathrm{~h}$ ), the carbon excretion rate (Table 2 ) and an estimated respiration rate of $12 \%$, we calculate an

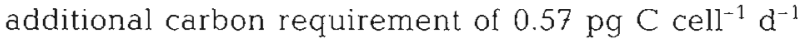
Based on mass balance of carbon under cyclostat conditions, a total level of $110 \mu \mathrm{M}$ DOC would be required to support observed growth rates. The glycerophosphate added to culture media would provide $108 \mu \mathrm{M}$ DOC. Glycerol has been shown to be an effective carbon source for mixotrophic phytoplankton (Lewitus \& Caron 1991). Also, DOC in coastal waters is several orders of magnitude above this level (Sugimura \& Suzuki 1988)

Fluctuating light has been considered important to algal photosynthesis and is also considered a possible source of error in estimates of primary production (Cullen \& Lewis 1988). Fluctuating irradiance appears to have no influence on the growth rate of Aureococcus anophagefferens but does influence carbon fixation. The higher carbon fixation rates observed in the fluctuating irradiance regime were most likely due to the higher photosynthetic efficiency as observed in the $\alpha_{p}$ values, suggesting that electron transport has become more efficient under fluctuating irradiance. The excess carbon was not contributing to growth, however, and may be lost as $\mathrm{CO}_{2}$ through photorespiration, especially considering that long-term excretion rates were 
actually lower in fluctuating irradiance. The presence of photoinhibition in fluctuating irradiance is also consistent with higher photorespiratory rates; however, cells are not exposed to photoinhibitory levels during culturing (Fig 3) The findings presented here agree with Cospers' (1982a) conclusions that photosynthetic rates of Skeletonema costatum were enhanced in fluctuating irradiance but that growth rate remained the same under equal daily quantum flux and excess carbon fixed under fluctuating irradiance was found to be lost through photorespiration.

The higher nitrogen content of cells exposed to fluctuating irradiance may in part be due to photorespiratory recycling of internal $\mathrm{NH}_{4}{ }^{+}$Alternatively, higher nitrogen quotas may be reflecting an accumulation of pigment-protein. Although accessory pigments were not measured directly, the higher in vivo absorbance in the Soret band of cells grown in fluctuating irradiance indicate that there were differences in accessory pigment content (Fig 4). The increase in photosynthetic efficiency $\left(\alpha_{p}\right)$ also supports this idea. This evidence along with the lower $\bar{a}^{*}$ value for fluctuating irradiance indicates that Aureococcus anophagefferens was acclimating to an irradiance somewhat below the average instantaneous irradiance of $70 \mu \mathrm{mol}$ quanta $\mathrm{m}^{-2} \mathrm{~s}^{-1}$ used in the fluctuating irradiance treatment. A decrease in $\bar{a}^{*}$ is a common response to acclimation to low light (Falkowski et al. 1985).

While high light-utilization efficiency of Aureococcus anophagefferens may explain its persistence once the photic zone is reduced to $80-100 \mathrm{~cm}$, it does not explain the initiation of a bloom. In summer, at the onset of a bloom, irradiance and nutrients are saturating and phytoplankton biomass $(95 \%<5 \mu \mathrm{m})$ is most likely grazer controlled by microzooplankton (D. J. Lonsdale, M. A. Frey, R. Mehran, G. T. Taylor \& R. M. Waters unpubl.). Mehran (1996) has found that protozooplankton may discriminate against $A$. anophagefferens when cell concentrations are $>2.5 \times 10^{5}$ cells $\mathrm{ml}^{-1}$, although discrimination below $2.5 \times 10^{5}$ cells $\mathrm{ml}^{-1}$ has not been observed. Based on the above model results, cell concentrations on the order of $10^{5}$ cells $\mathrm{ml}^{-1}$ ought to be controlled by nutrient concentrations or grazing Further work is required to elucidate the interactions between grazers and $A$, anophagefferens at the early stages of bloom initiation. Clearly higher grazing rates on phytoplankton other than $A$. anophagefferens could give this species a competitive advantage at the early stage of a bloom before light levels become limiting.

Acknowledgements. We thank Robert Strzepek and Paul J Harrison for their comments on early versions of the manuscript. Critical comments by William Henley, Osmund HolmHansen, and 2 anonymous revewers greatly improved the final manuscript. This research was supported in part by grants from New York State Department of Environmental Conservation, the Living Marine Resources Institute and the Waste Management Institute at Marine Sciences Research Center, State University of New York at Stony Brook. Partial support to A.J.M. was provided through the Kenneth P. Staudte award from MSRC. SUNY, Stony Brook

\section{LITERATURE CITED}

Bannister TT (1974a) Production equations in terms of chlorophyll concentration, quantum yield, and upper limit to production. Limnol Oceanogr 19:1-12

Bannister TT (1974b) A general theory of steady state phytoplankton growth in a nutrient saturated mixed layer. Limnol Oceanogr 19:13-30

Bidigare RR (1989) Photosynthetic pigment composition of the brown tide alga: unique chlorophyll and carotenoid derivatives. In: Cosper EM, Bricelj VM, Carpenter EJ (eds) Novel phytoplankton blooms: causes and impacts of recurrent brown tides and other unusual blooms. Lecture notes on coastal and estuarine studies. Springer-Verlag, Berlin, p $57-76$

Brand LE, Guillard RRL, Murphy LS (1981) A method for the rapid and precise determination of acclimated phytoplankton reproduction rates. J Plankton Res 3:193-202

Bricelj VM. Kuenstner SH (1989) Effects of the 'brown tide' on the feeding physiology and grow th of the bay scallops and mussels. In: Cosper EM, Bricelj VM, Carpenter EJ (eds) Novel phytoplankton blooms: causes and impacts of recurrent brown tides and other unusual blooms. Lecture notes on coastal and estuarine studies. Springer-Verlag, Berlin, p 491-510

Bruno SF, Staker RD, Sharma GM, Turner JT (1983) Pnmary productivity and phytoplankton size fraction dominance in a temperate North Atlantic estuary. Estuaries 6:200-211

Cosper EM (1982a) Effects of variations in light intensity on the efficiency of growth of Skeletonema costatum (Bacillariophyceae in a cyclostat. J Phycol 18:360-368

Cosper EM (1982b) Influence of light intensity on diel variations in rates of growth, respiration, and organic release of a manne diatom: comparison of diurnally constant and fluctuating light. J Plankton Res 4:705-724

Cosper EM, Dennison WC, Carpenter EJ, Bricelj VM, Mitchell JG, Kuenstner SH, Colflesh DC, Dewey M (1987) Recurrent and persistent 'brown tide' blooms perturb coastal marine ecosystem. Estuaries 10:284-290

Cosper EM, Dennison WC, Milligan AJ, Carpenter EJ, Lee C, Holzapfel J, Milanese L (1989) An examination of the envirommental factors important to initiating and sustaming 'brown tide' blooms. In: Cosper EM, Bricelj VM, Carpenter EJ (eds) Novel phytoplankton blooms: causes and impacts of recurrent brown tides and other unusual blooms. Lecture notes on coastal and estuarine studies. Springer-Verlag, Berlin, p 317-340

Cosper EM, Gary RT, Milligan AJ, Doall MH (1993) Iron, selenium and catric acid are critical to the growth of the 'brown tide' microalga, Aureococcus anophagefferens. In: Smayda TJ, Shimizu Y (eds) Toxic phytoplankton blooms in the sea. Elsevier, Amsterdam. p 667-673

Cullen JJ, Lewis MR (1988) The kinetics of algal photoadaptation in the context of vertical mixing. J Plankton Res 10: $1039-1063$

Dennison WC, Marshall GJ, Wigand C (1989) Effect of 'brown tide' shading on eelgrass (Zostera marina) distributions. In: Cosper EM, Bricelj VM, Carpenter EJ (eds) Novel phytoplankton blooms: causes and impacts of recurrent brown. 
tides and other unusual blooms. Lecture notes on coastal and estuarine studies. Springer-Verlag, Berlin, p 675-692

Dzurica $S(1988)$ The role of environmental variables, specifically organic compounds and micronutrients, in the growth of Aureococcus anophagefferens, the 'brown tide' microalga. Masters thesis, State University of New York at Stony Brook

Falkowski PG, Dubinsky Z, Wyman K (1985) Growth-irradiance relationships in phytoplankton. Limnol Oceanogr 30 $311-321$

Gobler CJ (1995) The role of iron in the occurrence of Aureococcus anophagefferens blooms. Masters thesis. State University of New York at Stony Brook

Guillard RRL, Ryther JH (1962) Studies of marine planktonic diatoms. I. Cyclotella nanna Hustedt, and Detonula confervacea (Cleve) Gran. Can J Microbiol 8:229-239

Jeffrey SW, Humphrey GF (1975) New spectrophotometric equations for determining chlorophylls $a, b, c_{1}$, and $c_{2}$ in higher plants, algae, and natural phytoplankton. Biochem Phys Pflanz 167:191-194

Langdon C (1987) On the causes of interspecific differences in the growth-irradiance relationship for phytoplankton. Part I. A comparative study of the growth-irradiance relationship of three marine phytoplankton species: Skeletonema costatum, Olisthidiscus luteus and Gonyaulax tamarensis. J Plankton Res 9:459-982

Langdon C (1988) On the causes of interspecific differences in the growth-irradiance relationship for phytoplankton. II. A general review. J Plankton Res 10:1291-1312

Lewis MR, Smith JC (1983) A small volume, short-incubation method for measurement of photosynthesis as a function of incident irradiance. Mar Ecol Prog Ser 13:99-102

Lewitus AJ, Caron DA (1991) Effects of light intensity and glycerol addition on the organization of the photosynthetic apparatus in the facultative heterotroph, Pyrenomonas salina (Cryptophyceae). J Phycol 27:578-587

Lively JS, Kuafman Z, Carpenter EJ (1983) Phytoplankton ecology of a barrier island estuary: Great South Bay. New York. Estuar Coast Shelf Sci 16:51-68

Lonsdale DJ, Cosper EM, Woong-Seo K, Doall M, Divadeeman A, Jonasdottir SH (1996) Food web interactions in the plank-

This article was presented by O. Holm-Hansen (Senior

Editorial Advisor), La Jolla, California, USA ton of Long Island bays, with preliminary observations on brown tide effects. Mar Ecol Prog Ser 134:247-263

Marra J (1978) Effect of short-term variations in light intensity on photosynthesis of a marine phytoplankter: a laboratory simulation study. Mar Biol 46:191-202

Mehran R (1996) Effects of Aureococcus anophagefferens on microzooplankton grazing and growth rates in the Peconic Bays system, Long Island, NY. Masters thesis, State University of New York at Stony Brook

Platt T, Gallegos C.L (1980) Modelıng primary production. In Falkowski PG (ed) Primary production in the sea. Environmental science research. Vol 19. Plenum Press, New York, p 339-362

Rhee GY, Gotham IJ, Chisholm SW (1981) Use of cyclostsat cultures to study phytoplankton ecology. In: Calcott PH (ed) Continuous culture of cells. CRC Press, Boca Raton, p $159-186$

Seiburth JM, Johnson PW, Hargraves PE (1988) Ultrastructure and ecology of Aureococcus anophagefferens gen. et sp. nov. (Chrysophyceae); the dominant picoplankter during a bloom in Narragansett Bay, Rhode Island, summer 1985. J Phycol 24:416-425

Sokal RR, Rohlf FJ (1981) Biometry, 2nd edn. WH Freeman and Company, New York

Sugimura Y, Suzuki Y (1988) A high-temperature catalytic oxidation method for the determination of non-volatile dissolved organic carbon in seawater by direct injection of a liquid sample. Mar Chem 24:105-131

Strickland JDH, Parsons TR (1972) A practical handbook of seawater analysis. Bull Fish Res Bd Can 167

Verity PG (1981) Effects of temperature, irradiance, and daylength on the marine diatom Leptocylindrus danicus Cleve. I. Photosynthesis and cellular composition. J Exp Mar Biol Ecol 55:79-91

Yentsch CS, Phinney DA, Shapiro LP (1989) Absorption and fluorescent characteristics of the brown tide Chrysophyte. Its role on light reduction in coastal marine environments. In: Cosper EM, Bricelj VM, Carpenter EJ (eds) Novel phytoplankton blooms: causes and impacts of recurrent brown tides and other unusual blooms. Lecture notes on coastal and estuarine studies. Springer-Verlag, Berlin, p 77-86

Manuscript first received: October 25, 1996

Revised version accepted: May 5, 1997 